Journal of

Strategic Management

(JSM)

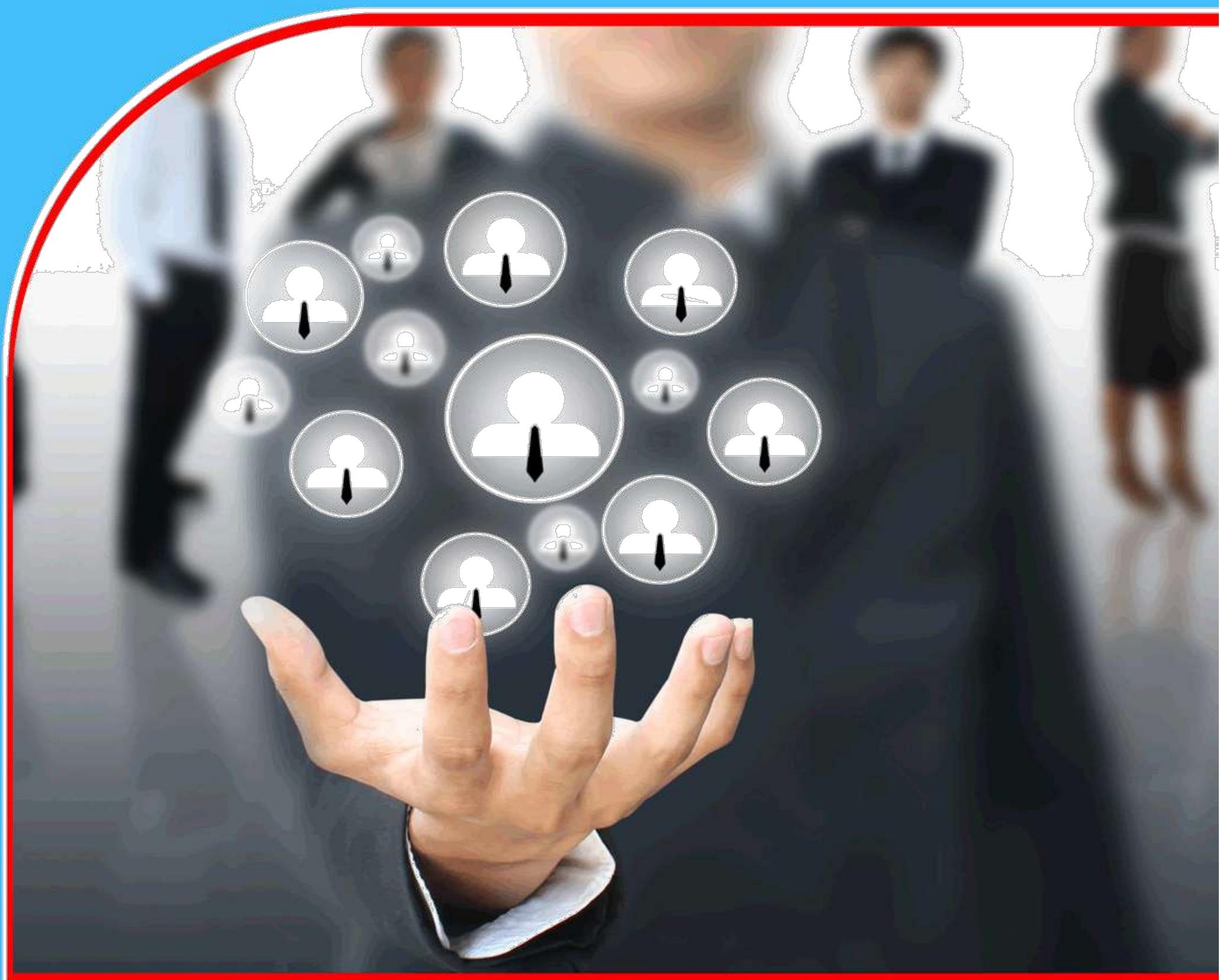

DETERMINANTS OF GREEN MANAGEMENT PRACTICES IN HOTELS IN KISUMU CITY, KENYA - A THEORETICAL FRAMEWORK 


\title{
DETERMINANTS OF GREEN MANAGEMENT PRACTICES IN HOTELS IN KISUMU CITY, KENYA - A THEORETICAL FRAMEWORK
}

\author{
Michael Murimi \\ Email: njue2010@gmail.com \\ Post graduate student \\ Maseno University, Kenya.
}

\begin{abstract}
Purpose: This conceptual paper aims at developing theoretical framework for determinants of green management practices in hotels.

Methodology: In order to come up with this theoretical framework, the researcher assumes a process of two phases the first stage will involve an explicit examination green management practices literature and what determines such practices in hotels. The succeeding stage was enhancements of the framework. The theoretical structure relies on the past theoretical explanations and empirical analyses in the fields green management and social sciences. Slack's resource theory and good management competitive theory informs this theoretical framework, the researchers clarify the justification for use of the two theories.
\end{abstract}

Findings: The researcher highlights by what method this reviewed theoretical framework may well be utilized to organize green management practices and its determinants in hotels especially in Kenya. Lastly, the researcher advances propositions that give foundations for empirical study to be carried out in the future.

Contribution to theory, practice and policy: Assimilating experiences from numerous disciplines, this paper emphasizes aggregated awareness regarding conceptualization of green management practices in hotels. This work inspires scholars and specialists to understand determinants of green management practices in hotels in Kenya.

Key terms: Green Management Practices, Determinants, Hotels in Kenya 


\section{INTRODUCTION}

The slogan "go green" is widely being used across many sectors in the world. It is being used to refer to the products practices which are ecofriendly, green, locally produced, organic, environmentally sound, biodynamic, energy efficient and sustainable. Green practices also bring various benefits related to operations like operational costs and energy consumption reduction, helps gain competitive edge, and improves the reputation of the hotel (Gao \& Natalia, 2014). Therefore, green initiatives are developing forces for an exceedingly competitive sector (Hsu, Han $\&$ Sheu, 2010). Green initiatives aid in reducing running cost while each facility should adopted best practices which suit how they operate and factors of their environment (Yusof, 2013).

Hospitality facilities lean towards having substantial ecological footsteps and the growth of its awareness is being evidenced by consumers seeking out hospitality facilities with green practices for instance, use of solar panels, adoption of waste reduction mechanisms and sustaining recycling bins (Hsu, Han, \& Sheu, 2010; Kang, Stein \& Heo, 2012). One of the big challenges for hotels is guaranteeing that the green ingenuities always meet the expectations clients' (Liu, Surya, Ma'ruf, Syahru, 2014; Chong \& Verma, 2014). Environmental awareness is growing and many organisations are beginning to present green products and services and hospitality sector has not been left behind (Modern, Roszayanah, Fauziah, \& Novel, 2012; Hengky, 2011; Mas'od, 2014). Globally, the hospitality sector is developing swiftly in its adoption and implementation of such green practices for preservation of natural resources and achieving desires and needs of green minded clients (Doherty, 2013). The world prominent chain hotels like, Starwood, Marriot, and Hyatt are proactively implemented green initiatives like energy and water saving, proper solid waste disposal, recycling, reusing and conservation activities aimed at providing opportunities to guests in hotels for lessening their negative effect to the environment (Hsu, Han \& Sheu, 2010; Millar \& Baloglu, 2011). Further, chain hotels have been found to be stronger adopters of green management practices when likened to other independent hotels, this is because of their nature of leveraging on economies of scale enhanced by uniform business practices (Imran, Dennis, \& Stefani, 2012)

The concept of green practices was introduced to reduce environmental problem (Ibrahim, Wang \& Yusof, 2016) and, such efforts of minimizing the environmental effects from the hospitality facilities may have a huge influence on both the hotels' finance and the environment (BJornefors \& KJelloson, 2014). Though there is a growing number of hospitality facilities becoming more devoted incorporating green practices and in their efforts to protect environment on daily processes, adoption of such environmental ingenuities are still negligible because of unappealing benefits likened to expenditures and inadequate knowledge about them (Abdul, Siti, Amran, Mahadi, \& Abustan, 2011).

In Africa, most of the hotels lack adequate green management policies, while there are those that engage in eco-friendly practices, other hotels do not have any clue regarding implementing green initiatives and their role towards mitigation of environmental challenges emanating from hotel operations (Mbasera, Saayman, Du-plessis, \& Kruger, 2016). In Kenya, Abdalla (2015) revealed that hotels in coastal region have adopted ecofriendly building designs, green practices like, management of solid waste, management of water and liquid waste, encourages green 
consumption and management of clean air as well as measures of water control. He further asserts that the key enablers for hospitality facilities to implement green practices are customer's attractions and hotel policies. There was a recommendation that hospitality facilities in Kenya should make employees aware and adopt green practices in their operation more so water consumption, energy consumption, waste management (Kariuki \& Odock, 2017).

Kisumu city in the lake region of Kenya is the largest town in western Kenya with an average 1200 classified bed rooms available for guests and continues to increase progressively (Leading-hotelsand-lodges, 2020). The city is host an inflow of tourists because of its proximity to areas of attractions like Ndere Island national, Kisumu impala national park, Kisumu national Musuems and Kiboko bay. Further, historic places like mighty Luo Worrior Luada Magere place, Kit Mikayi are part of tourist attractions. The city host academic and research Institutions, it is also known for sport fishing in fresh water Lake Victoria. The city has Kisumu Port connecting three countries, Kenya, Uganda and Tanzania. It has competitive standard hotels among other attractions. A research note on Kisumu revealed that the city is experiencing a boom in hospitality industry with many hotels and resorts coming up in the region and that the hotels experience high uptake during the holidays (Cytton, 2016).

\section{STATEMENT OF THE PROBLEM}

There are main environmental problems fronting the world today, the concerns include changes in global climate depletion of ozone layer, high rate of consumption of natural resources, pollution, and increase in solid waste (Mbasera, Saayman, Du-plessis, \& Kruger, 2016). Hotel sector is one of the resource consumptive sectors. The hospitality sector consumes substantial amount of resources, releases huge volumes of raw materials and wastes which exert a huge impact to the environment. Over reliance on non-recyclable materials and poor management of solid waste and is a threat to hotel managers (Kimeu, 2016). Hospitality facilities like hotels exert the highest negative effects towards the environment. Assessments reveals that an average hospitality unit like an hotel releases about $160 \mathrm{kgs}$ to $200 \mathrm{kgs}$ of carbon (iv) oxide per $\mathrm{m}^{2}$ of a hotel room floor range per annum and while water consumption by each guest in a night ranges between 170 litres to440 litres in a five star rated hotel. Other authors have revealed that one guest in a hotel produces $1 \mathrm{~kg}$ of waste in one night (Hsu, Sheu, \& Han, 2010), while in other hotels guest can generate up to 1kilogram of waste in a single day as revealed by (Losanwe, 2013). Organic waste accounts for $27 \%$ of the general waste generated by hotels (WRAP, 2015a). The amount of waste generated in Kisumu city on daily basis is approximated to be 200 to 250 tons with organic materials ranging between $62.5 \%$ to about $67 \%$ by weight (Gutberlet, Kain, Nyakinya, OLoko, Zapata, \& Campos, 2017).

Kisumu city like many urban centers is a developing city in the western part of Kenya and it is struggling with increase in waste generation, uncontrolled pollution from discarding waste and spilling over dumpsite (Sibanda, Obange, \& Awuor 2017). One of the factors contributing to the increasing rates of waste is increase in waste generated by a boom in hotel industry, where many hotels, restaurants and resorts are coming up in the region (Cytton, 2016). The range and extent of the influence that hotels exert towards environment proposes a crucial necessity for addressing this 
challenge, we there therefore need to answer the questions; do employees value the need to address increase in waste from their hotels? Do employees value eco-friendly initiatives in their hotels?

Looking at the quantity of waste generated and pollution from the hotel sector, it is important this sector to embrace green practices in their operations. Globally, the hospitality sector greening and using various certifications, green rating tools, emergence of green resorts, lodges and hotels. New founded and existing hotels marketing companies are now offering guidance and review on where to find the finest eco-friendly hospitality facilities across the globe. For instance, in 2013, Trip advisor launched Green-Leaders program with an intention of monitoring the green practices of hotels and ranked Berdessono hotel in California as the finest green hotel in 2014. In Kenya, green practices in hotel industry are being embraced slowly. There has been pressure from organizations like ecotourism Kenya, Tourism Regulatory Authority, National Environmental Management Authority, Kenya tourist board and Association of hotel keepers \& caterers, that are encouraging and making it a requirement that all tour operators and hoteliers should get green certifications and if they failed to do so, then organisations discourage potential clients from trading with these units (Ecotourism-Kenya, 2010).

Against this backdrop, this study seeks to investigate employees' awareness and perception on the management of green practices in hotel facilities in Kisumu City, Kenya. This is an area with scanty information (Mbasera, Saayman, Du-plessis \& Kruger, 2016). Hospitality facilities are being encouraged to adopt green practices as way of reducing negative impacts towards the environment and enhance preservation resources especially natural ones for sustainability (Doherty, 2013). Nevertheless, some hospitality facilities claim doing green practices while in the real sense they are not necessarily implementing them (Imran, Dennis, \& Stefani, 2012). Hence, it is important to investigate determinants of green management practices in hotels in Kisumu city, Kenya.

\section{THEORETICAL IDEOLOGIES UNDERPINNING THIS STUDY}

There are many reasons why organisations invest in developing superior environmental performance. Waddock and Graves (1997) proposes slack resources theory whose premise is that the organisations that have enough resources tend to apportion discretionary resources to activities that promote social responsibility like environmental enhancements. This is a worth investment that is purely designed to progress and increase competitive advantage of such organisations through image and reputation (Covin \& Miles, 2000). By allocating such resources towards implementing such superior green practices, hotels mostly gain reputation and better image and this may lead positive green performance. Good management viewpoint of competitive advantage theory instructs that organizations that have adopted advanced management pursue evolving bases for competitive advantage like green practices as way of satisfying their clients. Managers who are concerned with recognition of such greater green performance in public normally give a unique benefit that strengthens their competitive influence (Russo \& Founts, 1997). These theories inform this study, in that, irrespective of the nature hospitality units, its financial situations, or even its management strategies, there is a primary motive why they engage in green practices. While for some of them is to advance their image, build reputation eventually to obtain the competitive advantage others find it a reason for being social environmentally responsible. 


\section{The origin of green practices}

The origin of movement related to environmental concerns can be drawn early 1970 (Imran, Dennis \& Stefani, 2012). Environmental movement developed and grown rapidly especially 1990s; following disturbing information from the scientists that atmosphere of the earth was warming, and this marked the beginning of a green decade (Kirkprick, 1990). This green decade brought green clients who during this decade had appreciated how consumption of resources and their behaviors affect the entire earth. Riding on the upsurge of environmental apprehension, the green concept emerged and spread across all other sectors.

Green concept is in no way a new technique, they have been ongoing since human civilization (Reyolds \& Rahman, 2016). Pre-historic people worked with nature, they used natural approaches and resources for buildings. It is in the period of industrialization when human started using natural resources expansively for developing new commodities and services from them. The results for this wide use of natural resources were degradation of natural resources. The depletion of ozone layer in 1990s awakened human beings on the significance of green practices.

\section{Green practices in hotels}

A hotel is referred to as green hotels if it is ecologically friendly or eco-friendly hotels or environmentally friendly because the management in them is interested in programs like energy conservation, water conservation and reduction of solid waste and save costs of operations while protecting the environment (Green-Hotels-Association, 2018). A hotel that practices is green oriented is defined as a hotel which is environmentally friendly while at the same time energy conservation is practiced (ASEAN, 2013),

Green hotels association defined green hospitality unit as environmentally friendly unit where leaders are willing to establish programs that aim at saving energy, water and reducing solid waste with a final end of saving money- in their endeavor to protecting earth the only home of man, flora and fauna. Hence, these hotels diligently practice pure environmental management through their procedures, initiatives and practices that businesses have instigated with the aim of, eradicating, plummeting and if possible thwarting damaging environmental effects that may result from their operations (Cooper, 1998). Such practices include linen and towel reuse, low flow showerheads and faucets, recycling waste, fitting urinals with water free, automatic climate regulators, refillable bathroom features, light sensors and pure natural ventilation.

Green hotels are more environmental friendly especially in their efficiency and use of minimal water, energy, and resource as they provide quality goods and services (Lanjerwar, 2015). There are many paybacks that re associated with implementation of such green practices like increase in brand value, or even good image perspective from guests, increased profits, reduced liabilities and costs. Further, hotel contributes negatively to the environment and has a way of giving back they have come up with Corporate Social activities and social inventiveness (Tsechente, 2008).

Three major incentives why businesses go green are legitimation, competitiveness and ecological responsibility (Imran, Dennis \& Stefani, 2012). Most of the hotels with green practices certification are driven by hotel internal demands to meet the legal requirements, reduce environmental effects and risks (Bonilla, Najera, \& Font, 2011). However, in countries like 
Taiwan, this adoption of green practices is influenced by external attributions gains such as supportive reasons and economic benefits than internal attributions social and ethical responsibilities. For hospitality units implementing such green measures then organisational resources, self-efficacy, innovations, beliefs and external environments are vital for innovations sustainability (Chia, Kuo, \& Yueh, 2012)

\section{Areas of green practices in hospitality industry}

Mostly, green practices may be applied at the general organization level or inside guest rooms (Millar \& Baloglu, 2011). Basic green practices include conserving water, energy, and reducing waste (Yusof \& Jamaludin, 2013). Nevertheless, some operators go beyond basic applications to levels like pollution prevention, community involvement, sewage management, green buying policy, management of toxic waste, bio-climatic design, paperless technology, renewable energy, programs on environmental conservation, green transportations among others (Ayala, 1995).

The survey conducted by Yusof and Jamaludin (2013) that investigated green practices in different resorts with different geographical settings revealed that different resorts implemented diverse green practices owing to geographical settings and location that impacts natural resources like fresh energy, water, merchandises and backup infrastructures.

According to (O"Halloran, 2015), things like conserving water, lessening of greenhouse gasses emissions and potentially plummeting land contamination may be equally green strategies. While for sustainability purposes, ethics and corporate responsibility on green practices is very key (O'Halloran, 2015).

Green-Key-Eco-Rating (2015) is one of the global prominent eco-certification companies; it proposes that classification should be based on hotels processes optimization. The company suggests that there are nine major sustainable areas of processes that can decrease negative environmental effects in the large part of the hospitality unit. These areas include; water conservation, energy conservation, and management of solid waste. Also, control of interior air quality, management of hazardous waste, community outreach programmers, building infrastructure and land use. Green leaf standards and researchers view sustainable methods typologies as may be generalized and may include measures for instance energy and water saving, waste minimization and green purchasing practices (Chen, Legrand \& Sloan, 2013).

\section{EMPIRICAL REVIEW}

The literature related to green practices was reviewed under the following subheadings;

\section{The extent of employee determinants on green management practices}

Mbasera, Saayman, Du Plessis and Kruger (2016), studied environmentally-friendly practices to establish hotel's contribution in their efforts to mitigate negative environmental impacts; it was a qualitative study done in eight hotels as case studies. Data were collected by semi-structured and interviews from samples of managers from star-graded. The findings revealed that there are inadequate green management policies that exist but some hotels engage in few eco-friendly practices. The study revealed managers' lack awareness on environmentally-friendly practices that 
should be applied in hotels implying a need to create awareness on green management through training.

A study by Mair and Jogo (2010) to understand attitudes, motivations, and perceptions of environmental sustainability revealed that the primary sustenance for green practices arises from a few committed individuals who value the environment at personal level. A study by (Sucheran, 2013) on environmental Management in Hotel sector revealed that despite participants being aware of the harmful environmental effects of the hotel sector, programs on environmental management are at infancy stage and were unable to adopt them due to several constraints and challenges. Data were collected by use of survey from 60 hotel managers and about 400 hotel customers while interviews with sector stakeholders were done.

A study by Goh, Muskat and Tan (2017) on nexus between practices that are sustainable in Hotels and future Generation Y Students' in hospitality Career track decisions found that Gen Y Students have optimistic attitudes towards becoming employees in green and /or sustainable hotels. Data were collected via semi-structured interviews while analysis done by themes to classify patterns and themes for interpretations.

Jeongdoo (2009) studied linkage between environmental attitudes of top managers' and management of environment in hotel, where 3,699 online-survey request emails were sent to members of 11 state hotel and lodging associations. The study utilised on-line surveys to collect data. The study revealed that most hotels had greater participation in management of energy, water, and management of waste. The results showed a linkage between managers' attitudes on environment and organisational participation management on environment.

Chia, Yueh and Kuo (2012) study proposed integrated model of attitudinal and behavioural features while combining two theories; planned behaviour theory and theory of innovation adoption of green practices in restaurants Data were collected by use 350 questionnaire were distributed and 245 valid responses a rate of $71.1 \%$. The findings demonstrated that perceived behavioural and attitudes have significant influence on behavioural intentions and Perceived invention features have a significant influence on attitude and a secondary positive effects on behavioural intention toward adoption of green practices.

A recommendation by Chia, Yueh and Kuo (2012) that a larger sample from every restaurant should be used for future studies may be adopted in the current study to more comprehensively give answers to the set research objectives. Sun (2009) study investigated how personnel in hotel sector perceive green practices. Data were collected from eight green certified with a sample of 220 respondents. The findings illustrated that employees weighed their perception on green practices and attached importance to those that were beneficial to them compared to those that required them to change behaviour. There was a positive linkage between commitment of organisation and green practices. Generation $\mathrm{X}$ was revealed to be more perilous about green practices by hotels; this study proposes that hotels should carefully plan on green practices by motivating and training personnel.

Zengeni (2013) studied perceptions and awareness levels of Hotelier's about Green Tourism and its impacts on hotel costs operations. The study revealed that employee awareness is core when 
discussing green tourism as an indicator of cost control as employees are major drivers of green revolution. Michelle (2014) studied reaction employees towards sustainability environment initiatives in restaurants where key findings demonstrated employees unveiling high level of awareness on matters of environment further they showed a lot of pride, loyalty and satisfaction with their restaurant for engaging in sustainability initiatives. The data were collected through observations and semi-structured interviews.

\section{External determinants of green practices}

Ismail, Arifin, Deraman and Mostafa (2017) studied what influences adoption of green practices in the sector of hotels and factors with the highest influence among all of them. This study used data from articles, previous studies, journals and thematic analysis was done. Three factors that were identified include; consumers' support, costs, and employees' support. Costs of operations and employee support will be deliberated as internal factors while client's support was viewed as an external factor to the issue. Consumer support which is highly related to their attitudes and awareness on green practices was identified as the most influencing factor while employee support and costs were found to influence the managerial decision making on implementation of green practices in hospitality units.

Abdalla (2015) studied adoption of such green practices in hospitality and tourism sector by determining various green practices factors like consumption of green energy, building designs, and management of solid waste, liquid waste and air quality as well as control of emissions of greenhouse gases, a total of 24 hotels responded. The findings revealed that green practices have been not been fully adopted and where they have been adopted there is potential benefits.

Ru-jen and Chwen (2012) studied the way institutional theory impacts GSCM practices, its effects on performance of supply chain by examining if organisations succumb to organization pressure during the period of adoption while seeking financial efficiency. About 400 surveys were used to collect data from various organisations and another 200 surveys were issued to Council of professionals on Supply Chain Management. The results indicated that pressure from institutions has positive impact on adoption of GSCM practices and improves performance of organizations.

\section{The extent of Green management Practices in the Industry}

Doherty (2013) studied sustainable environmental practices in hotels and distinct events data were collected using semi-structured and forced-choice interview from of seven hotels and different events. The results revealed hotels were actively beginning and practicing sustainable environmental practices. Yusof and Jamaludin (2013) studied the rate of participation on green approaches by green hospitality sector. The study used observations and in-depth interviews. The finding showed three common areas where adoption of green practices by chain hotels has taken place include; waste, energy, and water. There were little participation on management of indoor air quality, systems of harvesting rainwater and renewable energy. Further monthly reviews related to environmental activities were conducted while staffs are trained on management of environment during the orientation day and time to time bases.

Pozzo, Do-Amaral, Sergio and Tachizawa (2016), studied the antecedents of satisfaction of customer satisfaction in the hospitality sector for hotel practices and sustainable development a 
total 473 respondents from seven hotels revealed that customer satisfaction significantly influenced adoption of sustainable practices by those hotels. Björnefors and Kjellsson (2014) studied how hotels deal with sustainability matters and to associate such sustainability among other hotels and in the global hotel sector. Data for the study was collected by use of semi-structured interviews and results revealed that all focus was put on aspects like; environmental aspect, waste, water; energy. Different hotels use different approaches towards sustainability. The research area use of eco-labels which are highly valued part compared to global hotel sector. Yusofa and Jamalufinb (2014) study was to identify green practices of Small Island Chalets operators in Kapas and Tioman Islands and to further establish if there is any existing difference between both islands. Data were collected using observations and in-depth interviews key differences were identified grounded on the results of only 6 case studies. The study recommends for more similar studies to be conducted and laid down the foundation for the current study on green practices in hospitality sector.

Chong, Choy, Bruns-Smith and Verma (2015) studied environmental sustainability in the Hospitality sector revealed that definite sustainability practices may be considered approximately worldwide in the hotel sector. The common green practices considered to be universal include fixtures such as water-conserving, programs for linen reuse. The linkage between sustainable environmental programs and customer satisfaction was found to be weak though quality hotels are progressively maintaining sustainability programs in their businesses. Yu-Chin, (2012) analysed practices and management environmental policies for the top fifty hotels using web pages as a platform for giving information related to environment. Only $46 \%$ hotels used web pages to relay environmental based information. Hotels that featured prominently with such web pages that demonstrated their environment commitment include; Wyndham, Accor, IHG, Whitbread, Rezidor, Hyatt, Sol-Melia, Scandic and TUI among others. The findings of content analysis recognized twelve environmental extent of focus. Data collected was limited information available on the website to the public therefore the study could not identify hotel sustainable environmental best practices. Nevertheless, the study endorses "best practice" by using hotel websites to advertise commitment of hotels towards environmental responsibility.

Wang, Wu, Qiao and Song (2018), studied an assessment of practices on energy-saving of hotel sector. A survey from 28 hotels revealed that $71.5 \%$ of those hotels have expressed programs and adopted them for environmental protection and energy saving mechanisms. Nevertheless, there is a gap on performance of energy and environment programs among different star rated hotels. The lower the star rating the lower the eenthusiasm for energy saving, while the opposite is also true, for example $63.6 \%$ of the five star rated hotels have approved measures on energy management and carbon auditing while none of the two star rated hotel has adopted them. Hulusi, Oguz and Mehmet (2015) study aimed at finding an answer to the question whether there is a difference on management of green practices when viewed from manager's perspective in Alanya and Rome rrestaurants. A total of 181 responses; with 98 and 83 from Turkey and Italian respectively were obtained. The results indicated that key similarities were found on water and energy saving practices, solid waste collections and reduced use of environmentally hazardous merchandises. Nonetheless, t-test findings revealed outstanding differences between preferences based on priority for Turkish and Italian restaurant managers over management of green practices. In-depth 
interviews for employees may be more valuable for the study and a recommendation by (Wang, Chen, Lee, \& Tsai, 2013) that it is a useful method to conduct studies that where all 9 aspects of green practices will be evaluated.

Ibrahim, Awan, and Yusof (2016) study aimed at determining the linkage between management of environmental practices and satisfaction of customers. Data were collected 281 respondents. The findings revealed that green and environmental practices had a significant linkage with satisfaction customer. Kariuki and Odock (2017) study was to investigate the extent of green practices that have been implemented and the connection between green operations practices and hotel operational performance. Data were collected from 47 hotels using a structured questionnaire. The findings revealed that hotels adopt various green practices concerned with, energy, waste generation, water, recycling and reduction while, employee awareness and training is core. Siti, Abdul, Amram, Abustan and Mahadi (2011) study examined the environmental initiatives and practices as implemented in selected Resorts. Despite the resorts being concerned on matters of environment, implementation of environment initiatives was minimal because high costs and unattractive benefits and lack of knowledge on such matters. Hence, the current study seeks to find out the levels of knowledge, awareness and perceptions regarding green practices and green certification in hospitality industry in Kenya.

Imram, Dennis and Stefani (2012) study aimed at establishing the extent to which hotels have embraced 'green' operational or eco-friendly approaches. About 1000 surveys were distributed to 166 hotels. Data were collected using a survey with five sections; waste reduction, energy management, recycling practices, green business and staff education. The findings showed that chain affiliated hotels because of their nature to leverage on economies of scale; they are strong adopters of green practices compared to other hotels through uniform corporate practices. Further, results revealed that size, mostly defined by number of hotel rooms had insignificant impacts on the level to which hotels are demanding to accomplish energy consumption. Alaa, Mohammed, Hesham and Mostafa (2016) study on evaluation for sustainable development in hotels adopted a quantitative approach and data were collected by use of questionnaires from hotel managers from a sample size of 121 hotels and the response rate was $46.28 \%$. The study highlighted the significance of the composite view of 79 indicators of SD concept which was organized into 10 dimensions.

\section{Summary of Literature Review and Research Gap}

The review of the literature reveals that a good number green practices studies have been done in other parts of the world and some in other sectors other than hospitality (Ru-Jen \& Chwen, 2012) in U.S and Taiwan manufacturing plant, those in hospitality sector includee in places like U.S (Bruns-Smith, Choy, Chong, \& Verma 2015); North America, (Imran, Dennis \& Stefani, 2012); California, (Doherty, 2013); Taiwan, Vienna, (Zitz, 2014); Malaysia, (Yusof \& Jamaludin, 2013), (Ibrahim, Awang, \& Yusof, 2016), (Siti, Amran, Abdul, Abustan, \& Mahadi, 2011); Portugal, (Pozo, Do-Amaral, Sergio, \& Tachizawa, 2016); Rome and Alanya (Hulusi, Oguz, \& Mchmet, 2015) and few in South Africa, (Mbasera, Du-Plessis, Saayman, \& Kruger, 2016); Zimbabwe, (Zengeni, 2013) and those carried out in Kenya were studied in hospitality facilities in Coastal region (Kariuki \& Odock, 2017); (Abdalla, 2015), though they were descriptive in nature, and used 
questionnaires to collect data. Further, most of the hospitality facilities are implementing green practices because they are internally driven by demand from the regulatory compliance, environmental groups, financial benefits, image branding, green clients pressure and competitiveness, (Yusof \& Jamuldin, 2013; Chia, Kuo, \& Yuch, 2012); (Bonilla, Najera, \& Font, 2011). However, the studies reveal a study gap on the determinants of green management practices mostly in hospitality facilities in Africa and that hospitality facilities are not implementing green practices because of a number of challenges experienced (Mbasera, Saayman, Du Plessis \& Kruger, 2016); (Sucheran, 2013).

A number of studies also focused on impacts of green practices to issues like hotel operating costs, (Zengeni, 2013); revisit intentions, green image, (Eunha, SooCheong, Jonathan \& Sejin, 2014). Also some of the studies were purely qualitative using in-depth interviews (Goh, Muskat, \& Tan; 2017; Mbasera, Du Plessis, Saayman \& Kruger, 2016; Zitz, 2014; Sucheran, 2013; Björnefors \& Kjellson, 2014) while others were purely quantitative and adopted questionnaires as method of data collection (Alaa, Mohammed, Hesham, \& Mostafa, 2016).

Some targeted managers only (Mbasera, Du Plessis, Saayman, \& Kruger, 2016); (Alaa, Mohammed, Hesham \& Mostafa, 2016; Jeongdoo, 2009; other utilized self-reported online surveys (Jeongdoo, 2009). Others relied on content analysis of online (Yu-Chin, 2012) others secondary data (Ismail, Deraman, Arifin, \& Mostafa, 2017). Most of them were descriptive studies and used a case study approach of one or two facilities (Michelle, 2014; Eunha, SooCheong, Jonathan, \& Sejin, 2014; Hulusi, Oğuz, \& Mehmet, 2015). Other studies focused only one aspect of green practices even though there are many other green attributes (Kasliwal \& Agarwal, 2015; Wang, Wu, Qiao, \&Song, 2018) others were more focused on either consumer or clients or on the employees but not both (Eunha, SooCheong, Jonathan, \& Sejin, 2014),

The background of study portrays a picture where green practices are of great significance in hospitality sector with huge benefits like reducing operational costs and energy consumption, enhancing the hotel's reputation and gaining a competitive edge (Gao \& Mattlia, 2014; Yusof \& Jamuludin, 2013). The findings from literature review illuminates a gap between on determinants of green practices mostly in hospitality facilities in Africa and those hospitality facilities are not implementing green practices because of a number of challenges experienced.

This current research paper proposes to seal the gap by studying the determinants of green management practices in hotels in Kisumu City, Kenya. The research will employ quantitative approach and all hotels in the city and seeks to find out challenges experienced by employees while implementing green practices. A recommendation by (Chia, Yueh, \& Kuo, 2012) that a larger sample from hospitality facilities should be used for future empirical studies will be adopted in the current study to comprehensively give answers the study questions. The proposed study will use structured questionnaires and observation method a way of collecting data.

\section{PROPOSITIONS}

It is a hypothesized that there is a relationship between the determinants, in this case employees' internal determinants and other external determinants and management of green practices in hotel. The following proposed objectives have been developed using existing ideas. 
- To investigate the influence of employee internal determinants on the management of green practices in hotels in Kenya

- To establish the influence of external determinants on the management of green practices in hotels in Kenya

- To investigate the extent of green management practices in hotels in Kenya.

- To investigate the linkage between determinants and management of green practices in hotels in Kenya

\section{The proposed conceptual framework}

Independent variables

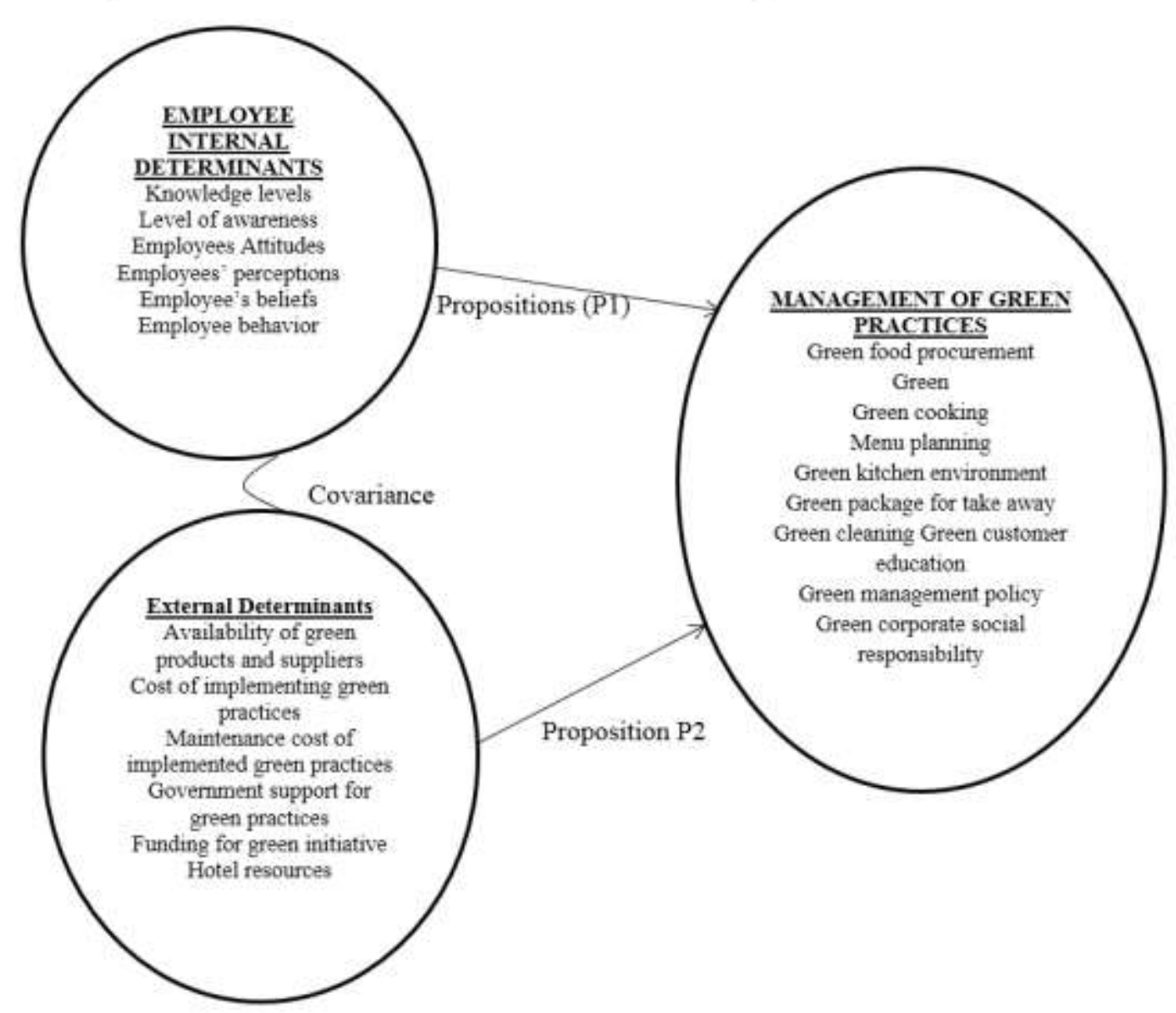

Fig.1.1. Proposed conceptual framework, (Authors, 2020)

RESEARCH IMPLICATION AND CONTRIBUTION

A theoretical framework is a structure which holds or strengthens a hypothesis that should be investigated and illuminates why the research should be carried out (Gabriel, 2013). The proposed investigations enhances the building of academic literature and proposes future empirical study. There has little empirical studies focusing on green management practices in hotels in 
Kisumu city, Kenya. To fill this gap the paper suggested this theoretical frame work for that purpose. Further, the proposed study would yield answers to questions on why, and how as well as to identify some major limitations that could be associated with propositions. Lastly, the paper responds to earlier demands for more studies related to green practices, (Chia, Yueh, \& Kuo, 2012); (Abdalla, 2015); (Mbasera, Saayman, Du-Plessis, \& Kruger, 2016); (Sucheran, 2013).

\section{CONCLUSION AND RECOMMENDATION}

Underpinning on Slack resources theory and Good management viewpoint of competitive advantage theory the proposed theoretical framework elucidates how employee internal and hotel external determinants influences green management practices in hotels in Kenya. The central standards for coming up with this theoretical framework were dependent on preceding theoretical justifications and empirical researches on green management practices in hotels and hospitality facilities. Justification for slack resources theory and Good management viewpoint of competitive advantage theory and their limited use in green practices researches has been underscored. Various authors have identified various metrics for green practices and determinants as well which have modified and used to develop propositions for the study.

Advanced propositions are structured in to four objectives. This is a unique paper because it advances a theoretical framework that opens opportunities for future empirical research. It doesn't propose a unique framework for green management practices Kenyan hotels rather enhances a framework to interface hypotheses, practice, and study on green management practices in hotels. With strong emphasis on literature from numerous disciplines, the paper underlines cumulative information on definition and demystification of green management practices concepts and its connection to determining factors. The paper builds future chances for an empirical cross-sectional survey study. This theoretical framework will be substantial in the conceptualization and expansion of future researches on green management practices for hotels in Kenya.

\section{REFERENCES}

Abdalla, M. (2015) Adoption of green practices in hospitality and tourism industry in Lamu County, Kenya, Nairobi, Kenya: Nairobi University.

Alaa, A., Mohammed, A. M,. Hesham, E. S., \& Mostafa, E. (2016) Evaluation Study for sustainable Development in hotels in some Tourists all Areas in Egypt. Journal of Faculty of Tourism and Hotels, Foyoum University., Vol. (10), No (2/2), September, 2016.

ASEAN, (2013) ASEAN tourism standards, Retrieved on 13 February 2016, from http://www.aseanyourism.travel/media/files/20130111081324_aseantourism_standards_book.pdf

Bjönefors, E., \& Kjellson, L. (2014) Hospitality and Sustainability: a case-study and comparison of the sustainability work by hotels in the Gothenburg area. Bachelor thesis..Gothenburg: University of Gothenburg.

Bonilla, P., Najera, J., \& Font, C. (2011) Environmental management decision-making in certified hotels. Journal of sustainable tourism, 19 (3), 361-381 
Bruns-Smith, A., Choy, V., Chong, H., \& Verma, R. (2015), Environmental sustainability in the hospitality industry: Best practices, gift participation and customer satisfaction (Electronic article) Hospitality Report, 15(3), 6-16.

Chen, J., Legend, W., \& Sloan, P. (2013) Sustainability the hospitality industry ButtenworthHeinemann.: Oxford

Chia, C., Kuo, C., \& Yueh, W. (2012) Green practices in the restaurant industry from an innovation adoption perspective; Evidence from Taiwan, International journal of hospitality management 31, 703-711; Taiwan.

Cytonn (2016) Research note: Focus on Kisumu; Kisumu investment opportunity August 2016, Cytonn Investments, Nairobi cytonn investments.

Deraman,F., Ismail, N., Arifin, A., \&Mostafa, M. (2017). Green practices in hotel industry; Factors influencing the implementation. Journal of Tourism hospitality and culinary arts, 9(2), 305316

Doherty, L. (2013, June). Environmental sustainability practices in the hospitality industry of Orange County, California senior project Thesis, California Polytechnic State University, San Luis Obispo, California.

Eco-tourism Kenya (2010) Eco-tourism report on green practices Nairobi: ecotourism Kenya.

Eunha, J., SooCheong, J., Jonathan, D. \& Sejin, H. (2014) The impact of eco-friendly practices on green image and customer attitudes An investigation in cafe setting; international journal of hospitality management, 41:10-20

Gao, Y. \& Natalia, A.S (2014) Improving Consumer satisfaction in Green hotels: The roles of perceived warmth, perceived competence and CSR motive, International journal of hospitality management

Goh, E., Muskat, B., \& Tan, A. (2017) The Nexus between sustainable practices in hotels and future Gen Y hospitality students career path decisions.,Journal of teaching and travel and tourism.

Green-Hotels-Associations, (2018) What are green hotels? https://www.greenhotels.com/

Green-key-eco-Rating, (2015) Green Key Eco rating

Gutberlet, J., Kain, J, H., Nyakinya, B., Look, M., Zapata, P., \& Compos, M. J. (2017) Bridging weak links of solid waste management in informal settlements; Journal of environment and development policy review, 26(1), 106-131

Hengky, S. H. (2011) "Technocentrism: Using Sustainable tourism concept to sustain environment, iimproving communities' life qualities and increasing economic growth on perak's destination, Malaysia. International journal of Business and Social Science, Vol.16, pp238-245 
Hulusi, D., Oğuz, N., \& Mehmet, D. (2015) A comparative study for green management practices in Rome and Alanya restaurants from managerial perspectives. Journal of tourism and Gastronomy studies, 3/2 (2015)3-11

Ibrahim, Y., Awang, Z., \& Yusouf, Y. (2016) Environmental management practices in the tourism industry in Malaysia. Man in India 96(12), 5241-5252.

Imran, R., Dennis, R., \& Stefani, S. (2012). How 'green' are North American hotels? An exploration of low-cost adoption practices United States. International journal of hospitality management 31(2012), 720-727

Ismail, N., Duraman, F., Arifin, A., \& Mostafa, M. (2017) Green practices in hotel industry: Factors influencing the implementation. Journal of Tourism, Hospitality \&Culinary Arts, 9(2), 305-316.

Jamaludin, M., \& Yusof, B. (2013) Best Practice of Green island Resorts. Asia Pacific International Conference on Environment-Behaviour Studies (pp. 105 (2013)20-29 London, UK; Elsevier Ltd

Jeongdoo, P. (2009) The relationship between top managers' environmental attitudes and environmental management in hotel companies. Blacksburg, Virginia: Faculty of the Virginia Polytechnic Institute and state University.

Kariuki, E., \& Odocks, S. (2017) Relationship between green operations practices and operational performance of hotels in the coastal region of Kenya, International journal of Scientific Research and Innovative Technology ISSN: 2313-3759, Vol. 4 No.6; June 2017

Kasliwal, N., \& Agarwal, S. (2015) A study on Indian consumer attitude and choice of preference for green attribute of hotel industry, Reserchgate, DOI: $10.17010 / / 2015 / \mathrm{v} 8 \mathrm{i} 1 / 61258$

Leading hotels and lodges, (2020), Gubernatorial address on the occasion of resumption of flights to Kisumu. July 2020, Kisumu, Kenya

Kimeu, D. (2016) Effects of waste management practices and operational performance of hotels in Mombasa County, Kenya, Master's thesis, Nairobi: University of Nairobi.

KirkPatrick, D. (1990). Environmentalism: the new crusade, Fortune 12 (February) 44-52.

Lanjewar, J. (2015) Green initiative by Hotels, Saiom Journal of Commerce and management,. A peer reviewed international journal, 2(1)

Lee, J., Hsu, L., Han, H., \& Kim, Y. (2010) Understanding how consumers view green hotels: how a hotel's green image can influence behavioural intentions, International journal of sustainable tourism, 18 (7), 901-914.

Lee, J., Hsu, L., Han, H., \& Shey, C. (2011) Are lodging customers ready to go green? An examination of attitudes, demographics, and eco-friendly intentions, International journal of hospitality management, vol 30(2), 345-355 
Journal of Strategic Management

ISSN 2520-0461 (Online)

Vol.5, Issue 1 No.5, pp 47-63, 2020

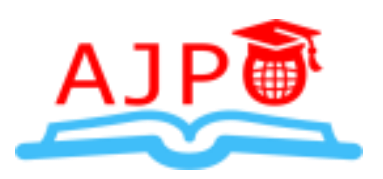

www.ajpojournals.org

Lita, R. P., Surya, S., Ma'ruf, M., \& Syahru, L (2014) Green attitude and behaviour of local tourists towards hotels and restaurants in West Sumatra, Indonesia, Procedia Environmental Sciences. Vol. 20, pp. 261-270.

Losanwe, I. (2013). Environmentally friendly luxury hotel case: Grand Palace Hotel, Riga, Latvia, Unpublished thesis, Latvia; Lahti University of Applied science.

Mair, J. \& Jago,L. (2010) The development of a conceptual model of greening in the business events tourism sector. Journal of Sustainable tourism, 18(1), 77-94

Mas'oud, A. C (2014). Determining socio-demographic, psychographic and religiosity of green hotel consumer in Malaysia, procedia-Social and behavioral sciences, Vol. 130, pp. 479-489

Mbasera, M., Du Plessis, E., Saayman, M., \& Kruger, M. (2016) "Environmentally friendly practices in hotels", Acta Commercil, 16(1) a362.http:dx.dol.org

Michelle, A. (2014) The green restaurant in practice; Employees attitude and behaviour towards environmental sustainability, Mid-eastern, United States

Miles, M., \& Covin, J. (2000) "Environmental Marketing: A source of Reputational, competitive, and Financial Advantage," Journal of Business Ethics, 23(3): 299-311.

Modern, H. A., Ros-Zayanah, J., Fauziah, A., \& Novel, L. (2012) "Green advertising and environmentally responsible consumer behaviour; The level of awareness and perception of Malaysian Youth." Asian social science, Vol. 8, No. 5, pp 46-54

Rahman, I., \& Reynolds, D. (2016) Predicting green hotel behavioural intentions using a theory of environmental commitment and sacrifice for environment, International journal of hospitality management.

Ru-Jen, L, \& Chwen, S. (2012). Why do firms adopt/implement green practices?- An institutional Theory perspective, International conference on Asia Pacific Business Innovation and Technology Management.

Russo, M., \& Fouts, P. (1997) A research based perspective on corporate environmental performance and profitability, Academic management Journal. 40(3), 534-559.

Sibanda, L.K., Obange, N. \& Awuor, F.O. (2017) Challenges of Solid Waste Management in Kisumu, Kenya Urban Forum 28, 387-402. https://doi.org/10.1007/s12132-017-9316-1

Siti, A.G., Abdul, N., Amran, A., Abustan, I., \& Mahadi, R. (2011) A field Survey of Environmental Initiatives at selected Resorts in Malaysia, World Applied science Journal (special issue if tourism \& hospitality), 12: 56-63, 2011.

Sloan, P., Legend, W., \& Chen, J. (2013) Sustainability in the Hospitality industry: principles of Sustainable Operations (2nd.Ed), New York: Routledge

Sucheran, R. (2013) Environmental management in the hotel and lodge sector in KwaZulu-Natal, South Africa, KWAZULU-NATAL

Sun, K. (2009) An investigation into hotel employees "perception of Green practices", Orlando, Florida: Electronic Thesis and Dissertations. https://stars.library.ucf.edu\%etd/4166. 
Waddock, S. A., \& Graves, S. B. (1997) The corporate social performance-financial performance link. Strategic Management Journal, 18(4), 303-319.

Wang, X., Wu, N., Qiao, Y., \& Song, Q. (2018) Assessment of Energy- Saving Practices of the Hospitality Industry in Macau, Macau: Macau University of Science and technology.

Wang, Y., Chen, S., Lee, Y., \& Tsai, C. (2013). Developing green management standards for restaurants: An application of green supply chain management, International journal of Hospitality management, 34, 263-273

WRAP. (2015a) Hotels: taking action on waste. .www.wrap.org.uk/sites/files

Yu-Chin, H. (2012) Hotel companies' environmental policies and practices: a content analysis of their web pages, International journal of contemporary Hospitality management, Vol. 24 No. 12012 pp. 97-121.

Yusofa, B., \& Jamaludin, M. (2014) Practices of small island chalet operators in East Peninsular Malaysia, SEAN- Turkey ASLI (Annual Serial Landmark International) conference on quality of life 2014, ABRA International conference on Quality of life, (pp. AQol2014, 26-28.,) Istanbul, Turkey

Zengeni, N. (2013) Hoteliers' Perception of the impact of Green Tourism on Hotel Operating Costs in Zimbabwe 1: The case of selected Harare Hotels. Australian Journal of Business and Management Research, vol.2 No. 11 (64-73) 